\title{
A szexuális életre nevelő könyv ajánlója 81 évvel ezelőttről
}

\author{
Recommendation for a book about sexual education from 81 years before
}

\author{
Szerző: Solymosy József Bonifácz, Kárpáti Tímea $\square$ \\ Nemzeti Egészségfejlesztési Intézet
}

Beküldve: 2016.09.01.

Kulcsszavak: szexuális életre nevelés; köznevelés; nőnevelés

Egészség XLIX. 475-6. füzet szept.- okt. 1935. 9-10. füzet 117-118. oldal

$A z$ „Egészség” címü folyóiratból eredeti helyesírással digitalizálva.

„Csaba Margit dr.: Amit a fiatalasszonynak tudnia kell.

Az ifjúság nevelésének mindmáig megoldatlan kérdése: a sexuális életre nevelés, mindkét nembeli ifjúságnak, a házasélet élettanába és lélektanába való bevezetése. Az iskola, melynek nyilvánossága legtöbbször nem tudja kiküszöbölni a tárgyhoz szükséges bensőséges komolyság profanizálását, - de meg legtöbbször az errevaló tanerő hiánya miatt is: alig alkalmas arra, hogy a nevelésnek ezt a nem nélkülözhető részét megadja. Így a családnak jut ez a feladat, s a családi élet bizalmas levegője valóban alkalmasabb is a kérdés megoldására. Egy ponton azonban megakad a családi nevelés lehetősége. - Az ifjúságot, különösen pedig a múvelt ifjúságot igen igényes szellemi nívón nevelték. Ezért a szellemi és testi világnak azokat a jelenségeit, melyek vele bármikép is kapcsolatba kerülnek, nem veszi egyszerúen tudomásul, mint megmásíthatatlan adottságokat, hanem igyekszik lényegüket megismerni s beilleszteni abba a gondolat- és ismeretrendszerbe melyet önmagának tudatosan megalkotott. A sexuális élet és a házasság sem olyan egyszerű tények többé a ma ifjúsága számára, amit folytatni kell, mert eleink is így csinálták, hanem olyan jelenségek, melyek a természetes életfunkciók síkjain kívül etikai, gazdasági, társadalmi és világnézeti síkokat is érintenek. Éppen ezért nem elégszik meg azzal a <felvilágosítással> amit a család - kivételektől eltekintve - e téren nyujtani tud, hanem szükségét látja olyan forrásnak, melyből igényeinek megfelelő nívón szerezheti meg ismereteit.

Ezt a - nevelés, közelebbről nőnevelés terén mutatkozó - szükségletet elégíti ki Csaba dr. könyve, mely logikus folytatása eddigi köteteinek: <<Amit a nagylánynak tudnia kell>>

Legújabb írásában Csaba Margit dr. magyarázattal és tanáccsal szolgál mindazokra az ismerethiányokra, problémákra és kétségekre, melyek a fiatalasszony életében sorrakerülhetnek. Beavat a fejlődéstan nehezen megközelíthető törvényébe: az ember születésének történetébe, a sejtek oszlásától az új ember világrajöveteléig. Bemutatja azoknak a babonás módszereknek hiábavalóságát, melyek a megszületendő gyermek nemét kívánnák előre meghatározni. A gyermek neme, s ezzel a férfiak nők közel egyenlő aránya a társadalomban: olyan alappillérje az emberiség békéjének és fejlődésének, hogy annak alakulásába nem engedhet beleszólást az Úristen. Hiábavaló tehát minden kísérlet: a társadalomélet megmásíthatatlan törvénye, hogy körülbelül ugyanannyi leány szülessék, mint fiú.

A biológiai kérdések tárgyalása mellett nagy figyelmet szentel Csaba dr. könyvében a lelki élet, a házastársak közötti harmónia problémáinak. Figyelmezteti a fiatalasszonyokat: nehogy azt higyjék, hogy csak addig kell gondot viselniök külsejükre, míg azt a férjük meghódítására akarják fegyverül használni. Aki házasságban él, arra különösen érvényes, hogy nem elég csupán a lelki szépséget gondozni, s a gondozott külsőről akkor sem szabad lemondani a fiatalasszonyoknak, mikor ránézve még oly nagyjelentőségű élmény tölti is be lelkét, mint a gyermekvárás, vagy a babagondozás. Lehetőleg kerülendőnek tartja, hogy az asszony a házi kötelességeinek 
ellátásán felül egyéb hivatalt is vállaljon. Nem előnyös ez azért, mert lehetetlen két úrnak a kenyéradó gazdának és a háztartásnak, gyermeknek egyformán jól szolgálni. De a férj önérzetét is sérti az a tudat, hogy a család eltartásában a feleség segítségére is rászorul.

A legnagyobb hangsúllyal és a legféltóbb gonddal a házas élet etikájáról beszél Csaba dr. E szempontból valósággal a gyermek és az anyaság kultusza ez a könyv, mint Tóth Tihamér professzor előszavában mondja: Minden sora mögött ott érzik az ifjúság: a házasság csak úgy lehet kedves és Isten és emberek előtt, ha betölti a hivatását: a gyermek világrahozatalát és felnevelését. Ezt kívánják az Isten kinyilatkoztatott törvényei és ezt az igaz értelemben vett hazafiság íratlan parancsai. Nem megoldás tehát, ha mesterségesen akadályozzák meg a gyermekáldást, mert a sok múvi vetélés tönkre teszi az anyát testi egészségében és lelkileg-idegileg egyaránt. Mert lelkiismeretes ember nem tudja sokáig ép lélekkel viselni a gyermekgyilkosság szörnyú lelkiismereti vádját - $s$ azt a veszedelmet, melyet az állam törvényes rendelkezéseinek megszegése jelent. Van azért kivezető út is ebből a nehéz kérdésből. A szerző ezt is megmondja. Ha ugyanis a házastársak egészségi állapota úgy kívánja, hogy ne szülessék a házasságukból utód, vagy ha alapos lelkiismeret vizsgálat után úgy látják, hogy a gazdasági helyzetük miatt nem képesek több gyermek eltartására: a katholikus egyház által is elfogatott Knaus - Ogino - Smüldess - féle módszert alkalmazhatják, mely kiküszöböl minden mesterséges eszközt, s pusztán a minden tekintetben kívánatos időnkénti önmegtartóztatás útján tudja a célt: a gyermekáldás megakadályozását szolgálni. Ennek a módszernek az alkalmazása természetesen lelkiismereti kérdés, s éppen ezért csak addig tarthat, amíg a gyermek születést akadályozó okok fennállanak.

Csaba Margit dr. könyve minden vonatkozásban számol a vallás és erkölcs igazságaival, és a komoly ismeretekre, kétkedéseik eloszlatására vágyó fiatalasszonyok igényeivel. Írása tehát jeles munka, a nőnevelés terén eddig mutatkozott hézagok kiküszöbölésére mindenképpen alkalmas."
Nyolc évtized alatt a téma jelentősége nem változott, viszont a megközelítése sokat bővült. Napjainkban a párkapcsolatok, házasságok növekvő labilitásának, felbomlásának jelentős gazdasági és társadalmi következményei ismeretében alapvető társadalompolitikai célnak tekinthető a családi élet minőségének és stabilitásának javítása. A HBSC felmérések szerint az a tendencia tapasztalható a fiatalok körében, hogy egyre korábbi életévekre tevődik a párkapcsolat kialakulása és az első szexuális kapcsolat, ami az adott társadalom normáihoz igazodó szexuális kultúrához, a szexualitással kapcsolatos ismeretek elsajátításához, az érzelmi érettség és a felelősségtudatos viselkedési attitűd kialakulásához is kapcsolódik. ${ }^{1}$

Éppen ezért mind a családi-, mind a szexuális életre nevelés egyre nagyobb hangsúllyal kerül előtérbe. A kiegyensúlyozott és értékközvetítő családi életet a családban lehet igazán megtanulni, hiszen ez a személyes kötődések elsődleges szintje. A nevelési-oktatási intézmények és a velük együttmúködő családok közös feladata a gyermekek nevelése minden téren, legyen az a családi életre nevelés vagy a szexuális kultúra.

A köznevelésről szóló törvényben illetve a Nemzeti Alaptanterv alkalmazásáról szóló rendeletekben mindkét témakört érintik a köznevelési intézmények nevesített feladatai között. ${ }^{2,3}$ A családi életre nevelés, a szexuális kultúra és nevelés fogalmak gyakran jelennek meg együtt, hiszen ezek szorosan összefüggnek, egymásra épülnek.

A nevelés erősen kapcsolódik a diákok (fiúk, lányok egyaránt) környezetéhez, az életkorukhoz, sajátos tapasztalataihoz. Az életkor, a nemi szerep, a szociális háttér, a szexuális érdeklődés, a diákok fejlettségi állapota és egyéni kapacitása is erősen befolyásoló tényezők, tehát a korcsoport igényeinek, tudásának és fejlettségének megfelelő szinten, személyi központú megközelítéssel minél hamarabb, már óvodás korban, vagy az általános iskola alsó tagozatában - tehát nem a kamaszkorban - lenne érdemes elkezdeni a szexuális nevelést. A skandináv országokban az alapfokú oktatás teljes ideje vagy egy része alatt heti egy órában oktatnak szexualitással, családtervezéssel kapcsolatos ismereteket.

A család (követendő, vagy elutasítandó) mintát nyújtó szerepe mellett az iskolai környezetre hárul a feladat, hogy felelős párkapcsolatok kialakítását, a családi életben felmerülő konfliktusok kezelését 
megalapozó képességeket készséggé fejlessze. Az ismeretek átadásán túl, az attitűdformálás is csak kontextus-orientált szemlélettű pedagógiai munkával lehetséges.

„A szexuális nevelésben szerepet vállaló tanárnak gondolkodásában rugalmasnak, módszereiben pedig korszerúnek kell lennie. Szinte évről évre változtatni szükséges a módszereket és a témákat. A diákok egyre korábban kezdenek érdeklődni, hiszen információforrásaik bővülnek a technika fejlődésével, az akceleráció (emiatt is) egyre jellemzőbb." ${ }^{4}$ Ennek a naprakész, rugalmas attitúdnek a szükségességét nem csak az e-alapú (nem feltétlenül életkor specifikus, korrekt) információk szélesedő elérhetősége indokolja. A (népegészségügyi) szakembereknek kihívást jelent a nemzetközi szinten is erősödő "gender és sex" szakmai hangsúlyainak differenciálása, a klasszikus család-modellektől eltérő minták elterjedése, ami a sztereotípiák megváltoztatásának szükségességét is felveti. Erre egy érdekes példa a bécsi közlekedési lámpák figuráinak kísérleti jelleggel való bevezetése néhány kerületben. ${ }^{5}$ [1. ábra]

1. ábra: Gyalogos-átkelést irányitó közlekedési lámpák piktogramjai Bécsben

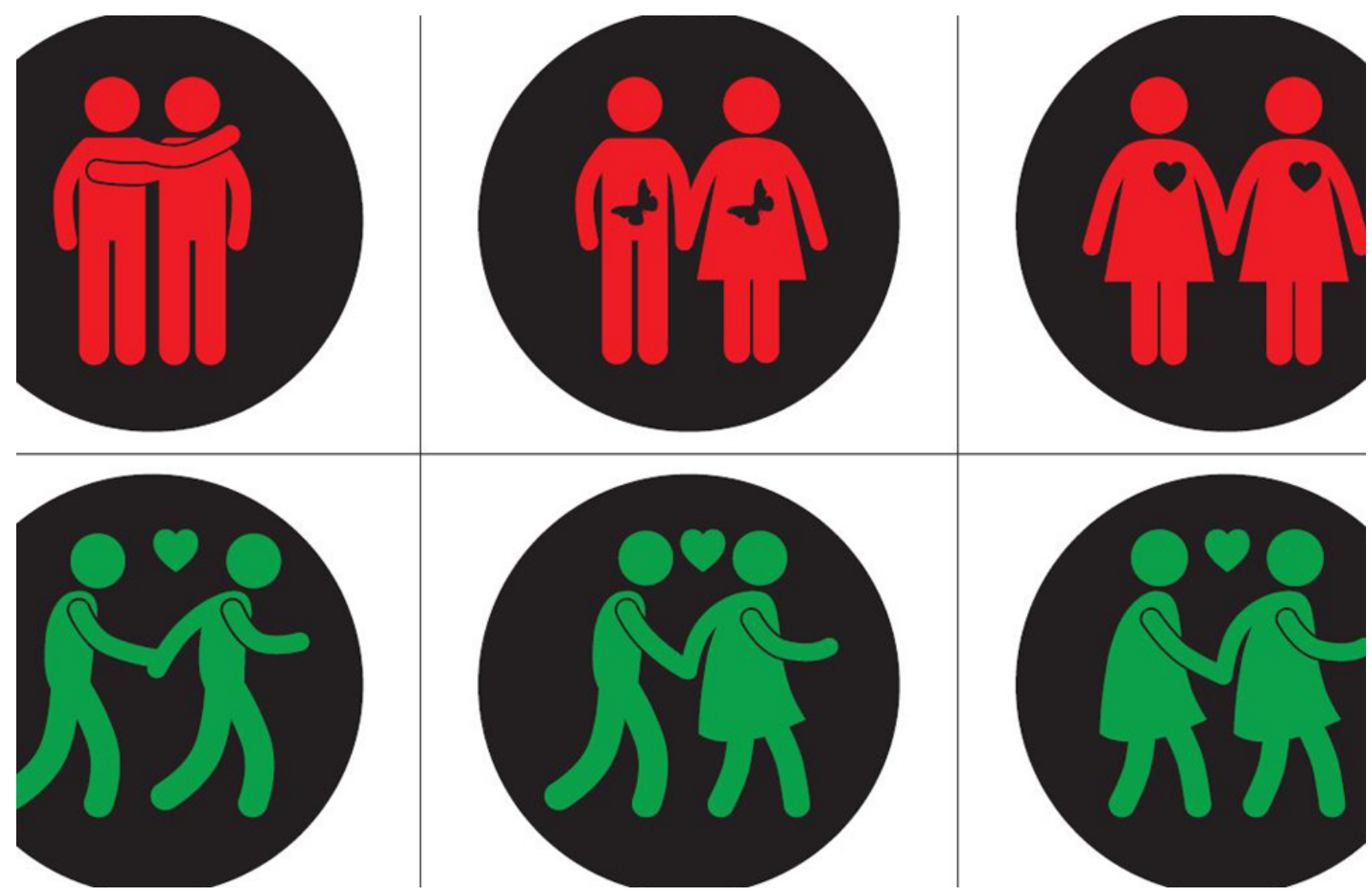

Forrás: http://www.österreich.at/chronik/Wiener-Ampelpaerchen-ab-jetzt-zu-zweit/188004220

A pedagógusképzés tantárgyi struktúrája és az Oktatási Hivatalban akkreditált pedagógus továbbképzések közül ebben a témában elérhető programok minimális száma és óraszáma, valamint a kérdéskör érzékenysége miatt még mindig jellemző, hogy a pedagógusok kevésbé felkészültek és motiváltak. Általános megoldás az intézményekben, hogy a témát akció jelleggel dolgozzák fel, akár úgy, hogy „fehér köpenyes” külső előadót hívnak meg, egy-egy felvilágosító osztályfőnöki vagy biológia tanóra keretében, és mint elvégzett tevékenységet, kipipálják a feladatot.

Ezt a problémát ismerték fel és igyekeznek kezelni például azok a civil kezdeményezések is, amelyek a hagyományos iskolai programokon túlmutatnak. Egy ilyen példa, a speciális nevelési igényűekre is fókuszáló kiadvány-sorozat, mely segíti a pedagógusok munkáját, a szülőket és a gyermekeket, hogy a 
felnövekvő generáció kiegyensúlyozott, tartós, biztonságos és boldog családi élet kialakítására legyen képes. ${ }^{i, 6}$

Az Egészséges Magyarország 2014-2020 stratégia keretében kiemelt részterületként került meghatározásra a lakosság lelki egészségének fejlesztése, fenntartása. ${ }^{7}$ Ennek keretében külön nevesített cél, hogy a vágyott és tervezett gyermekek nagyobb száma szülessen meg és nőjön fel szeretetteljes családban. Ehhez elengedhetetlen feladat, hogy a lelki egészséggel kontextusba helyezve kerüljön sor a szex-edukációra.

Ma már egyértelmü, hogy a fiatalok szexuális nevelése kapcsán nem elégséges csak a fogamzásgátlásra, a nemi élethez kapcsolódó betegségekre, a szervek múködésére illetve a higiénés tennivalókra szorítkozni, ám napjainkban leginkább ez jellemzi az intézmények gyakorlatát. A szexualitás lelki-, mentális-, szociális aspektusaira is szükséges a nevelés során különös hangsúlyt fektetni, hogy a fiatalok az elvárt társas-, társadalmi szerepeik betöltésére alkalmassá váljanak és autonóm, felnőtt életre legyenek képesek. ${ }^{8}$

Tehát, amikor jelezzük, hogy a nyolc évtized alatt a téma jelentősége nem változott, viszont a megközelítése jelentősen bővült, akkor azt úgy értjük, hogy a „régi” módszertanok, megközelítések folyamatos átgondolására, aktualizálására is szükség van, melyhez a népegészségügyi szakemberek, egészségfejlesztők is hozzá tudnak járulni, segítve a pedagógusok nevelő munkáját.

${ }^{1}$ http://www.egeszseg.hu/szakmai oldalak/assets/cikkek/16-05/egeszseg-es-egeszsgegmagatartas-iskolaskorban2014.pdf (Elérve: 2016.08.25.)

${ }^{2}$ http://njt.hu/cgi bin/njt doc.cgi?docid=139880.321413 (Elérve: 2016.08 .26 .)

3 http://njt.hu/cgi bin/njt doc.cgi?docid=149257.256438 (Elérve: 2016.08.26.)

${ }^{4}$ Fábián Róbert-Dr. Simich Rita: Meglévő és működő modellprogramok, valamint az iskolai szexedukációs események értékelése. HIV/AIDS-prevenció. Az ifjúság biztonságos szexuális életre nevelése. OEFI. 2006. http://mek.oszk.hu/08100/08125/08125.pdf (Elérve: 2016.08.26.)

${ }^{5}$ http://www.xn--sterreich-z7a.at/chronik/Wiener-Ampelpaerchen-ab-jetzt-zu-zweit/188004220 (Elérve: 2016.08.26.)

${ }^{6}$ http://sexeducatio.hu/index.php?subpage=celcsoportok3 (Elérve: 2016.08.26.)

7http://www.kormany.hu/download/e/a4/30000/Eg\%C3\%A9szs\%C3\%A9ges Magyarorsz\%C3\%A1g e\%C3\%BC strat\%C 3\%A9gia .pdf (Elérve: 2016.08.26.)

${ }^{8}$ Nemzeti Lelki Egészség Stratégia (tervezet): http://www.pef.hu/pef/resources/documents/nemzeti lelki egeszseg strategia tervezet pef kiegeszitesekkel.pdf (Elérve: 2016. 08.26. )

\footnotetext{
2003-ban az Oktatási Minisztérium hivatalos tankönyvvé nyilvánította a tankönyvcsaládot, mely tanári és diák-munkafüzetekből áll:

1. Forrai Judit: értelmi sérültek érzelmi, szexuális élete és nevelése (tanári útmutató)

2. Forrai Judit, Lengyel Adél: Én-kép-kirakó/alsó tagozatos tanulóknak,

3. Forrai Judit, Lengyel Adél: Felnőttország-járás/felső tagozatos tanulóknak)
} 